\title{
Archaeological traces of hunter-gatherer seasonal occupation in Western Coastal Estonia from the second half of the 6 th millennium to the end of the $3^{\text {rd millennium } B C}$
}

\author{
Kristjan Sander ${ }^{1}$, Aivar Kriiska ${ }^{2}$ \\ 1 Kristjan Sander (the corresponding author), School of Humanities, Tallinn University, Tallinn, EE \\ kristjans@hot.ee \\ 2 Aivar Kriiska, Institute of History and Archaeology, University of Tartu, Tartu, EE; aivar.kriiska@ut.ee
}

\begin{abstract}
Results of archaeological surveys of paleocoastlines in the Western Estonian Lowland are discussed with paleogeographic reconstructions. Mapped sites and stray finds can be dated to the period between the end of the Pre-Pottery Mesolithic and the end of the Neolithic (roughly 53002000 cal BC). Uniquely for Estonia and neighbouring countries in this time frame, the overwhelming majority of the sites are aceramic (and the rest feature very few pottery finds) and the find $d i$ versity is otherwise low, too. The findings are interpreted as traces of seasonal occupation and mobility, for the first time demonstrated in the Eastern Baltics on such a large scale.
\end{abstract}

KEY WORDS - hunter-gatherers; seasonal mobility; ephemeral sites; Narva Ware; Comb Ware

Arheološki sledovi sezonskih poselitev lovcev in nabiralcev na območju zahodne
priobalne Estonije od druge polovice G. tisočletja do konca 3. tisočletja pr. n. št.

IZVLEČEK - V članku predstavljamo rezultate arheoloških pregledov paleo-obale na območju Zahodnoestonske nižine in jih razlagamo s pomočjo paleogeografskih rekonstrukcij. Kartirana najdišča in naključne najdbe lahko datiramo $v$ čas med koncem predkeramičnega mezolitika do konca neolitika (v grobem od 5300 do 2000 pr. n. št.). Velika večina najdišč je akeramičnih (ostala najdišča pa imajo zelo malo lončenine), pa tudi sama raznolikost najdb je majhna, kar je edinstvena značilnost za Estonijo in sosednje države $v$ tem časovnem obdobju. Najdbe razlagamo kot sledove sezonske poselitve in mobilnosti, kar smo prvič pokazali za območje Vzhodnega Baltika v tako velikem obsegu.

KLJUČNE BESEDE - lovci-nabiralci; sezonska mobilnost; kratkotrajna najdišča; najdbe tipa Narva; glavničasta keramika

\section{Introduction}

The current study presents new results of archaeological surveys in the Western Estonian Lowland (Estonia, Europe) at the eastern coast of the Baltic Sea (Fig. 1.A) conducted in 2015-2020. Although more than 400 Stone Age sites were previously known in Estonia (Sikk et al. 2020), different parts of the country are studied to different extents (Fig. 1.B). The most understudied subregion is the Western Esto- nian Lowland that takes up most of the mainland coastline of Western Estonia between the Gulf of Finland and the Gulf of Pärnu, covering about $6000 \mathrm{~km}^{2}$ (about $13 \%$ of the area of Estonia).

In spite of the proximity of the much better studied Pärnu area to the south and the Western Estonian Archipelago to the west (Fig. 1.B) (e.g., Kriiska 2001; 
2003; Kriiska, Lõugas 2009), only four Stone Age settlement sites and one burial site (Jalukse, Torrv 2016.123) were known before 2015 (Kriiska, Mandel 1996; Kriiska et al. 1998; Kriiska 2001.Fig. 3; 2001b.Fig. 4; 2004.172; Jussila, Kriiska 2004.1315), although the apparent need for surveying the subregion was recognized already in the 1930s (Laid 1931.357-358).

The aim of the present study is to map the Stone Age landscape use and its dynamics along the Baltic Sea paleocoastlines from the Litorina Sea Transgression Maximum (LTM) in about 5300 cal BC (corresponding to the Late Mesolithic in the Estonian archaeological periodization, Fig. 2) to the Limnea Sea development stage (final part of the Neolithic) in about 2000 BC (Hang et al. 2020; Kriiska et al. 2020.17). For that, two study areas were selected, covering more than half of the area of the West Estonian Lowland (Fig. 3).

\section{Materials and Methods}

As a prerequisite for the study, paleolandscape of the Western Estonian Lowlands was modelled basing on the LIDAR digital elevation model (DEM) and the Estonian Soil Map (Estonian Land Board 2017. 2020). The sea levels and locations of the coastline were reconstructed by the coast displacement curves for South-West Estonia (Rosentau et al. 2011), Tallinn (Northern Estonia, Muru et al. 2017) and Lake Veskijärv (northern study area, Grudzinska et al. 2013), taking into account the post-glacial rebound (Saarse et al. 2003; 2006). The paleosurfaces of the present-day raised bogs were reconstructed with the help of the Estonian Soil Map and the database of geological studies of Estonian peatlands (Orru 2020). No effort was taken to reconstruct past water levels of inland lakes as no paleolakes were included in the survey. All other topographic data is provided by the Estonian Land Board (2021).

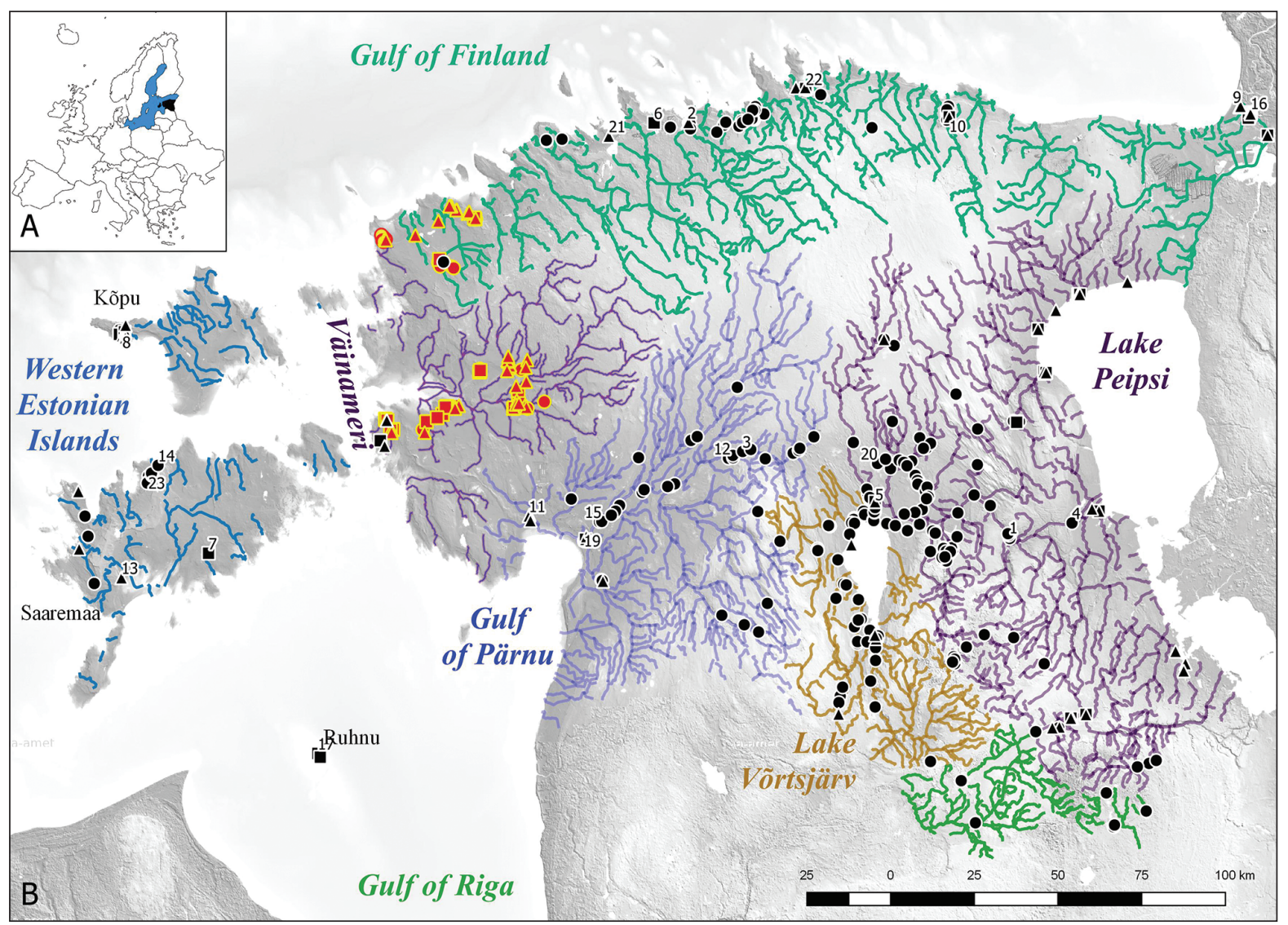

Fig. 1. A The location of Estonia (black) and the Baltic Sea (blue) in Europe. B Previously known (black) and newly discovered (red) Stone Age settlement sites projected onto the present-day Estonian grayscale elevation model together with water streams, divided by drainage basins by different colours. Dots PrePottery Mesolithic, rectangles Narva stage, triangles Comb Ware stage. Numbers denote settlement sites mentioned in the article and not located on other figures: 1 Ihaste, 2 Jägala-Jõesuu sites, 3 Jälevere, 4 Kavastu, 5 Kivisaare, 6 Kroodi, 7 Kõnnu, 8 Köpu sites, 9 Kudruküla, 10 Kunda Lammasmägi, 11 Lemmetsa sites, 12 Lepakose, 13 Naakamägi, 14 Pahapilli II, 15 Pulli, 16 Riigiküla I, 17 Ruhnu II, 18 Siimusaare, 19 Sindi-Lodja sites, 20 Umbusi, 21 Tallinn Vabaduse väljak, 22 Vihasoo III, and 23 Võhma sites. 
Two main study areas (Fig. 3) were chosen to feature different landscape types (isthmuses, bays, river mouth lagoons, rivers, islands and islets at various distances from the mainland) characteristic to Coastal Western Estonia. The Litorina Sea paleocoastlines in the northern study area were fairly articulated, featuring two isthmuses embracing a wide bay, presently the Suursoo mire. Between the isthmuses, the paleocoastline of the bay is smooth, cut by several small streams. The biggest stream entering the bay is the River Vihterpalu, forming a lagoon at its mouth. This study area also includes the Elbiku paleoisland, separated from the mainland by some $15 \mathrm{~km}$ of sea during the LTM. The southern study area is located south of the present-day Matsalu Bay. During the LTM, Matsalu Bay stretched about $25 \mathrm{~km}$ further eastwards, being about $35 \mathrm{~km}$ wide. Today, its eastern coast is well traceable as a wide arc of coastal formations between Üdruma and Avaste, cut by the River Kasari and its tributaries. Inside the bay, the present-day hills of Lihula, Lihutsi, Kloostri and Kasari formed an archipelago similar to the small islands in present-day Väinameri between the mainland and the island of Saaremaa. Some examined paleoislands (Massu, Salevere Salumägi) were situated outside of the bay in the open sea. In addition to these two main study areas, the shores of Kasari and Vigala rivers flowing to the southern study area were surveyed as far upstream as possible (about 17 and $44 \mathrm{~km}$ from the paleocoast at Teenuse, respectively).

As no organics enabling radiocarbon dating were gathered from any of the sites, approximate dating is currently possible only by the coastline displacement model (Jussila, Kriiska 2004) and comparatively by archaeological finds. The elevation of a site was calculated as the mean elevation of its finds in masl without outliers (a Z-score smaller than -3 or larger than 3). For clusters of finds within the error margin of a single GPS point, only one point was used. For sites located at the paleocoast or in the coastal zone, the terminus post quem (TPQ) was calculated. The minimum ele- vation of the finds relative to the sea level was assumed to be zero (the TPQ means the earliest time when the site was above the contemporary sea level). The coordinates of the sites and TPQs are presented in the Table 1 (supplement at http://dx.doi. org/10.4312/dp.48.24).

In the further discussion, the sites will be divided into three zones by their proximity to the paleocoast:

- inland sites discovered while surveying the banks of the Kasari and Vigala rivers;

- coastal zone sites on the banks of rivers and brooks up to $10 \mathrm{~km}$ from the paleocoast;

- coastal sites in the immediate vicinity of Littorina Sea coastal formations originating from the LTM or younger;

- island sites on paleoislands or islets.

The primary method of fieldwork was fieldwalking and gathering finds from the surface. Occasionally $30 \times 30 \times 60 \mathrm{~cm}$ test pits were made. At least three spatially close finds were grouped as a settlement site. Groups of finds were recorded as different sites

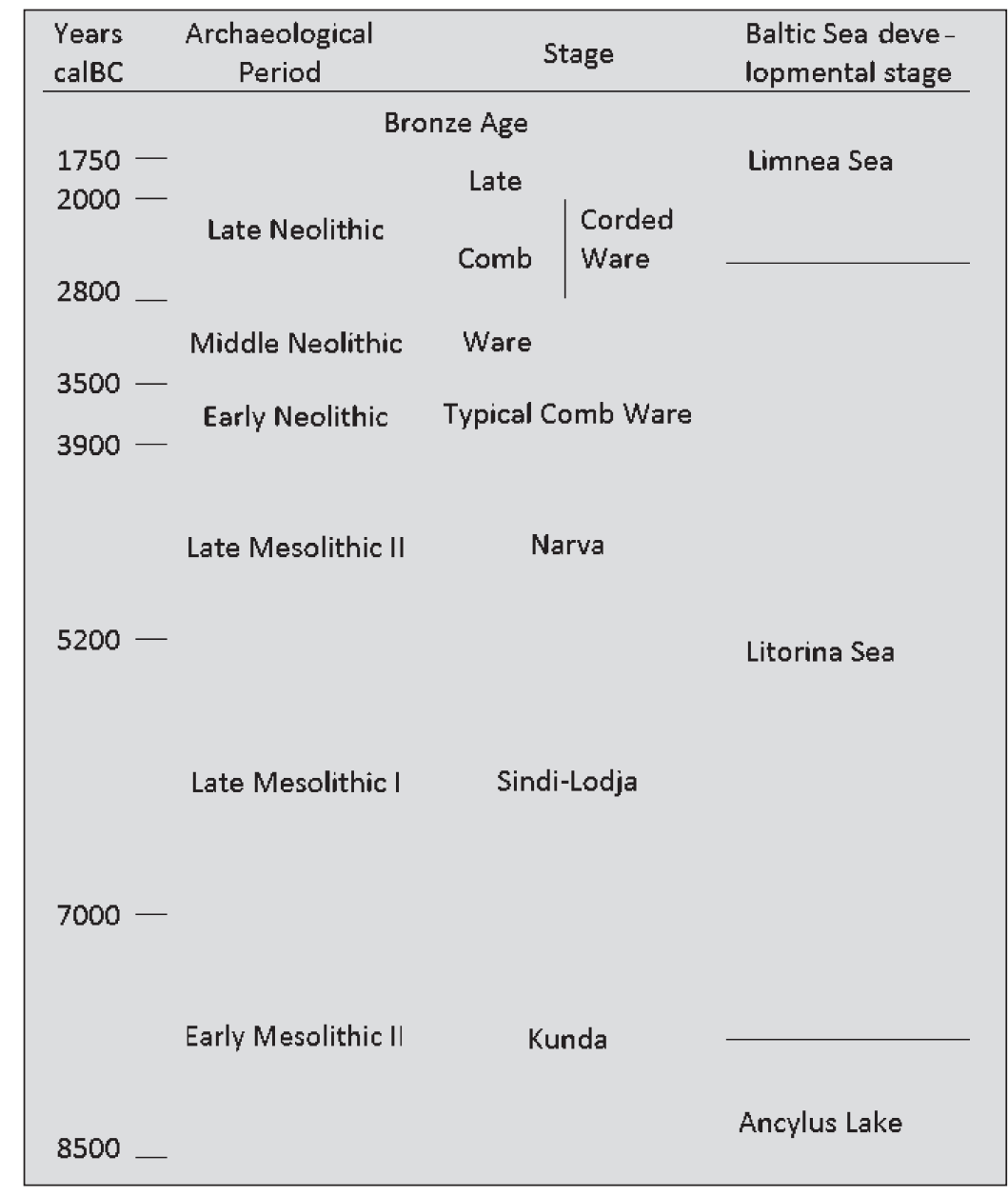

Fig. 2. Estonian Stone Age periodization together with Baltic Sea developmental stages (Kriiska et al. 2020.17; Hang et al. 2020). 
if separated by a visual barrier (most often, afforestation), located at different elevations or spatially associated with coastal formations at different elevations. The division of closely located GPS findspots into sites thus often reflects the present land use and surface conditions. The locations of all findspots were recorded by handheld GPS with minimum precision $\pm 8 \mathrm{~m}$.

Finds could have been collected only from areas with open ground: agricultural land, gardens, forest clearings and haulways. Therefore, the quantity of finds for each site does not indicate the intensity or nature of human activity during the time of depo-

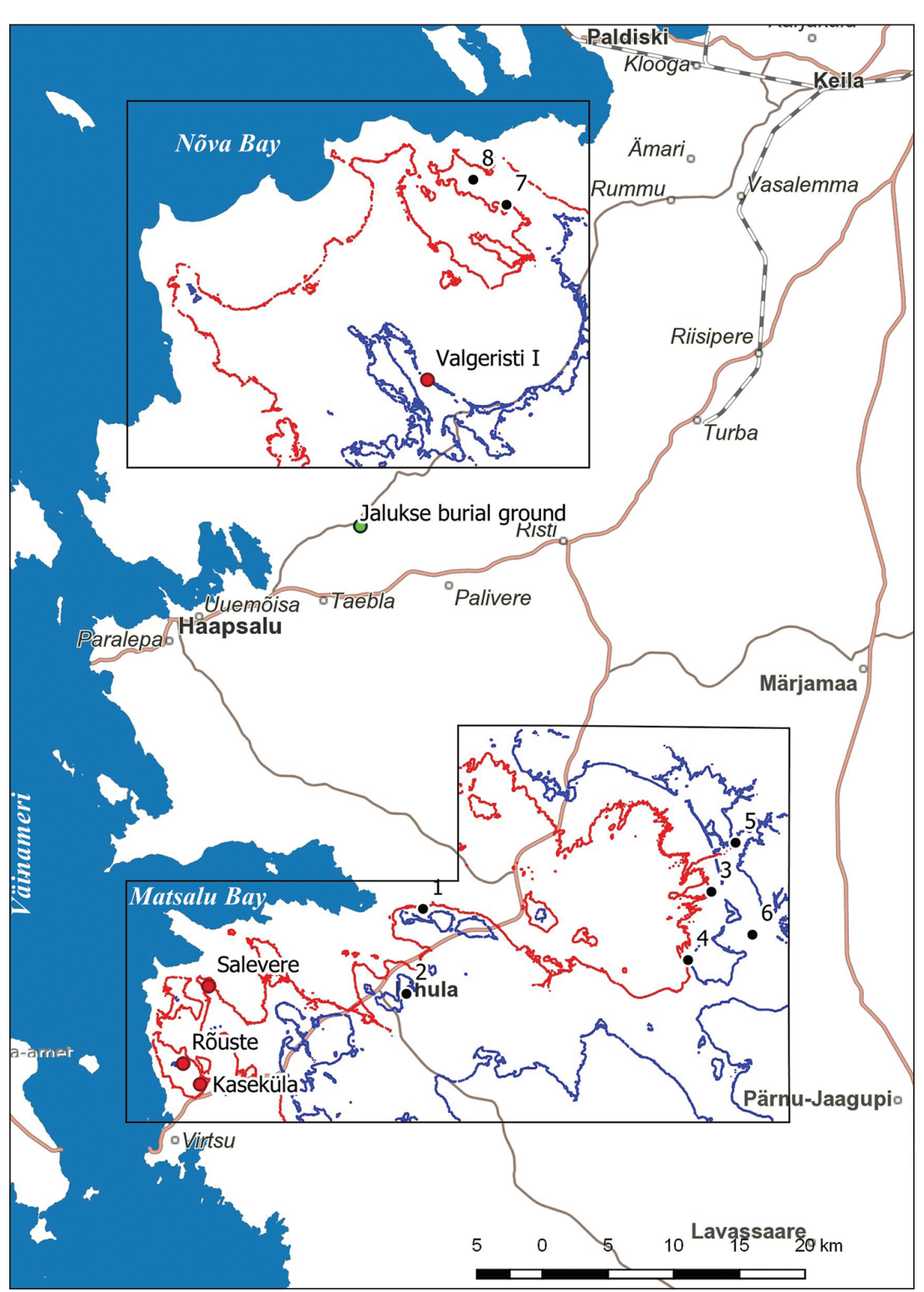

Fig. 3. Location of the study areas in the Western Estonia with paleocoastlines for 5300 cal BC (blue) and 4000 cal BC (red) projected on the present-day Estonian map with previously known settlement sites (red dots), burial ground (green dot) and stray finds (black dots: 1 Kloostri, 2 Lihula, 3 Oese, 4 Avaste, 5 Tiduvere, 6 Kesu I, 7 Harju-Risti, 8 Vilivalla). sition but the present-day finding conditions. The spatial orientation of the sites does not necessarily reflect the landscape use during the time of deposition either, as two adjacent sites might be separated by a strip of land with more difficult finding conditions. Similarly, the lack of finds from any particular area might be attributed to the lack of open ground.

The routes for fieldwalking traced Litorina Sea coastal formations, identifiable from the LIDAR elevation model and often visible on the ground. If possible, adjacent areas at different elevations were also checked for comparison. However, the goal of the fieldwork was to find as many sites as possible, not to survey a statistically representative sample of the surface. The overwhelming majority of finds are spatially associated with coastal formations, water streams or both. This might reflect a research bias towards areas with visible landforms, but the trend is in line with the current research on Stone Age settlement site location choice in Estonia (Sikk et al. 2020).

\section{Results}

\section{Finds}

In total, 2185 Stone Age finds were gathered. In addition to 2131 finds from 99 sites, 54 stray finds were collected from 38 locations. The newly discovered sites amount to one fourth of all Estonian Stone Age sites published before the current study (Fig. 1; Sikk et al. 2020). None of them have been published before except the locations of Kõmmaste $\mathrm{V}$, Kesu II and Ojapere II-III sites (O.c.). As the number of finds gathered by fieldwalking depends heavily on surface conditions, it is not indicative of the intensity of the site use.

The vast majority of finds are lithic artefacts. There are only 27 sherds of Stone Age ceramics among the finds ( 2 of 
Narva Ware, 15 of Comb Ware and 10 of Corded Ware vessels). 18 lithic finds exhibit signs of secondary processing. Among these are 8 flint and 2 quartz scrapers, 3 flint and 2 quartz retouched flakes and 3 flint arrowheads. 2 flint and 4 quartz flakes and 2 flint blades bear clear signs of use wear. The evidence of stone grinding is scarce: there are two adzes (from 0jaküla I and Teenuse II) and a fragment of grinding stone (from Küünimäe II).

The most common lithic material is quartz followed by Carboniferous, Silurian and Cretaceous flint and other lithic materials. As the number of finds is quite small for most of the sites, spatially close sites at close elevations with similar archaeological material were grouped for statistical overview of lithic material use (Tab. 1, supplement at http://dx.doi.org/10. $4312 /$ dp.48.24). Sites with a small number of finds and no adjacent sites were left out of the analysis.

\section{Utilized landscape types}

The number of inland sites (2) is surprisingly small, indicating low Stone Age human activity on the inland shores of water streams. The majority of the sites in the coastal zone (17) can be dated to the Neolithic Comb Ware stage by the finds, most of the rest having only a few finds registered. A notable exception is the Kesu II site, probably used during the Pre-Pottery Mesolithic, as indicated by a large share of blades. The group of coastal sites is the most numerous one (47), with TPQs ranging from the PrePottery to Comb Ware stage. Thirty-three sites are located on the islands, islets or peninsulas formed after the LTM, indicating continuous use of islands starting at latest in the Narva stage.

\section{Pre-Pottery Mesolithic and Narva stages}

In the northern study area, numerous sites were located on the barrier separating the Vihterpalu River mouth lagoon from the Nõva Bay (the Valgeristi sites; Fig. 4) and along the western (inland) coast of the lagoon (the Küünimäe sites). The southern study area (Fig. 5) also features a river mouth lagoon at the lower reach of the River Velise (Tõnumaa and Ojapere sites).

A radically different landscape is represented by the cape sites. In the northern study area, a number of them are clustered in the Kõmmaste village, situated at the end of the peninsula, forming the eastern coast of the Nõva paleobay (Fig. 4). The strip of land at the cape was about $600 \mathrm{~m}$ long and up to $150 \mathrm{~m}$ wide between 5300 and 5000 cal BC, completely open to the sea. The Nurme I and the Üdruma sites in the southern study area are similarly situated near the tip of the peninsulas at the mouth of a bay (or in the case of Üdruma, possibly on a coastal islet soon to become such a peninsula).

Small paleoislands became utilized during the Narva stage at latest. This is best observable in the case of the eastern Massu paleoislet in the second study area, where the cluster of finds at the Massu I site covers the central part of the eastern islet in about $4000 \mathrm{cal} \mathrm{BC}$ or somewhat earlier (Fig. 6.A). The overwhelming majority of the Massu I finds consists of quartz with some Silurian flint present. The same is probably true about the Massu III site and the higher part of the Massu IV site on the western islet while at least some finds from the lower part of the Massu IV site were deposited during the Comb Ware stage at earliest. The Lihula I site might be even earlier, with TPQ around 5000 cal BC (Fig. 5).

While the Massu, Lihula and Kirbla islands were parts of a coastal archipelago a few kilometres away from the coast, the Elbiku paleoisland in the northern study area was situated about $15 \mathrm{~km}$ from the coast during the Pre-Pottery and Narva stages (Fig. 4). If the Elbiku island finds of higher elevations (Elbiku VIII, IX, XI) were deposited at the coast, then human presence began in the Pre-Pottery Mesolithic. Most of the Elbiku sites can be associated with Narva stage coastlines.

\section{The Comb Ware stage}

Both Vihterpalu and Velise river mouth lagoons ceased to exist before the beginning of the Comb Ware stage (Figs. 7, 8), and newly formed lagoons in the northern study area have been investigated on minimal scale due to heavy afforestation. The use of the banks of the Velise river mouth at Ojapere continued after the end of the lagoon, where adjacent sites together take up about 13 hectares. A small number of Comb Ware sherds are present among the finds. In addition to 0japere II-III sites, some Comb Ware sherds were also found from the Teenuse IX riverside inland site.

In the eastern part of the northern study area, the pattern of utilizing capes continued (Risti I, Risti III and Vihterpalu I sites and Hatu I and Vihterpalu II stray finds) during the first half of the Comb Ware stage.

The paleoislands in the southern study area gradually merged with the mainland, becoming peninsulas (Fig. 8). Stone Age sites are common along their 


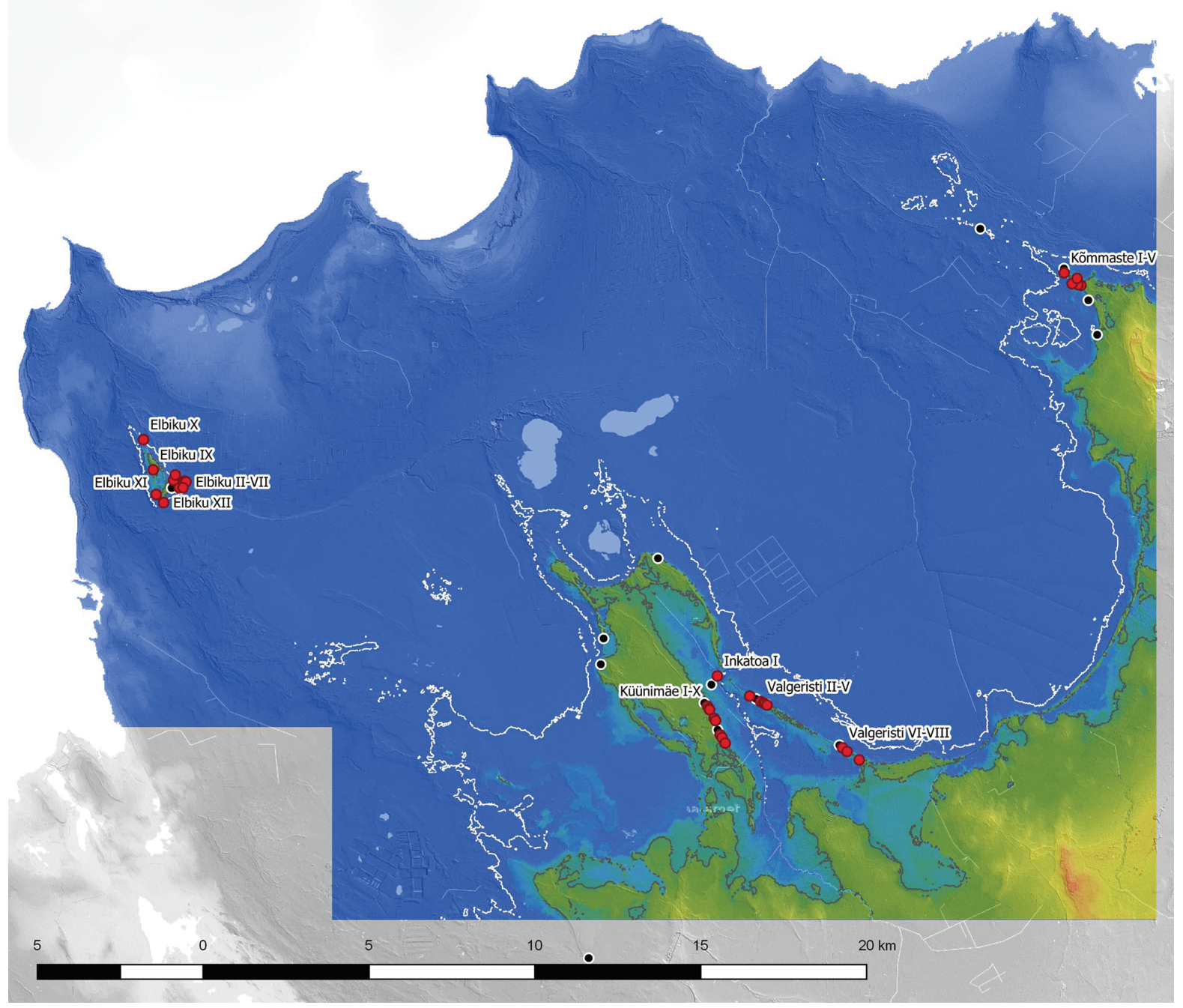

Fig. 4. Sites (red dots) and stray finds (black dots) discovered in the northern study area together with coastlines in 5300 cal BC (land denoted by green) and in 4000 cal BC (white).

coastlines at relevant elevations. In the Massu IV site, the Comb Ware stage landscape use is attested by a relatively large number of Carboniferous flint finds and a rhombic bifacial arrowhead (Fig. 6.B). However, only quartz bits were found from the $\mathrm{Sa}$ levere I site, although the TPQ does not allow an earlier dating than the middle of the Comb Ware stage (the same is true about the coastal Änglema I site in the northern study area). The latest TPQ for the Elbiku paleoisland is 3850 cal BC (Elbiku XIII).

The lowest site of the Massu cluster is Massu V, the elevations of which $(9.5-11 \mathrm{~m})$ correspond to the coastline of the peninsula in about $2600 \mathrm{cal} \mathrm{BC}$, roughly contemporary with the previously known Kaseküla site (Fig. 3). East of the Massu V site, about $200 \mathrm{~m}^{2}$ of an Early Iron Age stone enclosure was excavated in 1973 (Lang 2007.78-79.246; Tõnisson 2008.255) but no Stone Age finds were recovered. The large majority of coastal zone sites by the tribu- taries to the River Kasari in the southern study area (Fig. 8) have a high percentage of Carboniferous flint combined with a very low percentage of flint blades. These two traits combined support dating to the Comb Ware stage even in the absence of pottery sherds.

\section{Discussion}

No excavations have been carried out at the newly discovered sites, and no finds datable by radiocarbon methods have been obtained from the surface. Besides coastal chronology TPQs, well-researched background information on lithic material use makes aceramic sites roughly datable by the proportions of different lithic materials and stylistic features of the artefacts.

First, during the $7^{\text {th }}$ and $6^{\text {th }}$ millennia $\mathrm{BC}$, a change in stone usage occurred throughout coastal Estonia as Silurian flint was mainly replaced by quartz (Kri- 
iska, Sikk 2014.51-52), the reasons for which are unclear. Second, the share of flint blades (including fragments and tools made from blades) is generally higher in the Estonian Pre-Pottery Mesolithic (e.g., Pulli, Umbusi, Lepakose, Siimusaare, Ihaste, Sindi-Lodja II, Kavastu, Kivisaare and Jälevere sites, where it ranges from $10 \%$ to $40 \%$; Jaanits, Ilomets 1988.54; Kriiska et al. 2003.36; Tvauri, Johanson 2006.4243; Kriiska, Lõugas 2009.Fig. 26.5), than in the Late Mesolithic Narva stage sites (e.g., in the north-Estonian Vihasoo III and Kroodi sites in a range of 16\%; Kriiska 1997.9). Third, while Carboniferous flint is present in several Mesolithic settlement sites (e.g., Sander, Kriiska 2018.77-78; Kriiska, Khrustaleva 2020.41-42), the inflow of that material appears to have decreased significantly before the LTM. It reappeared as a typical material used by people also using the Comb Ware pottery (Moora et al. 1935.45-46; Yanits 1959.334; Jaanits et al. 1982. 77; Kriiska 2015). However, the share of quartz finds could exceed $90 \%$ of all lithic finds at some Comb Ware stage sites.

The indicators listed above work in combination (an early dating is justified if the share of blades among the flint finds and the share of flint among lithics are both high). In regard to the present study, the dynamics of the lithic material use and artefact typology described above (1) rule out the dating of the newly discovered coastal sites with a high share of quartz to a significantly earlier period than the LTM; (2) allow dating the coastal zone or inland riverside sites with a high share of Carboniferous flint and a low number of flint blades to the Comb Ware stage.

The most striking feature of the material found at the newly discovered sites regardless of dating is the low assemblage diversity, including almost total lack of pottery sherds and very few finds associable with stone grinding or wood chopping. Out of 99 StoneAge sites, sherds of Narva or Comb Ware were present in only six (Narva Ware: Kõmmaste V (2), Comb Ware: Teenuse IX (2), Ojapere II (4), III (7), IV (1), $\mathrm{V}$ (1)) while the TPQ is later than the introduction of pottery for 64 sites. In addition to pottery sherds, one fragment of a grinding stone (Küünimäe II) and two adzes (0japere I, Teenuse II) were found. A previously known stray find of a stone axe could be associated with the Kesu I site.

The observation of relatively large Estonian mainland areas featuring only small sites with low assemblage diversity is novel to the present work. A number of aceramic sites of the Narva stage or sites with

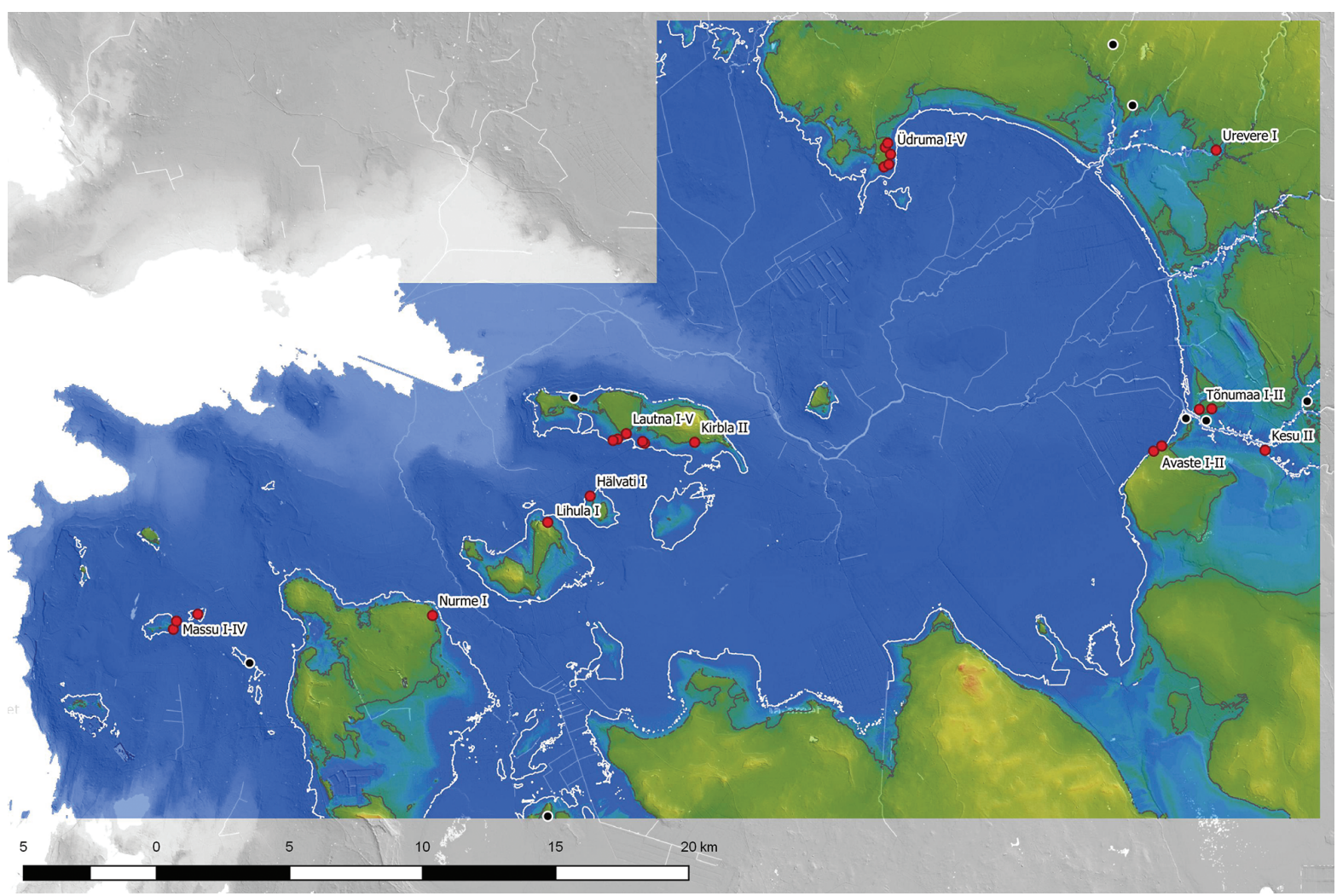

Fig. 5. Sites (red dots) and stray finds (black dots) discovered in the southern study area together with coastlines in 5300 cal BC (land denoted by green) and in 4000 cal BC (white). 


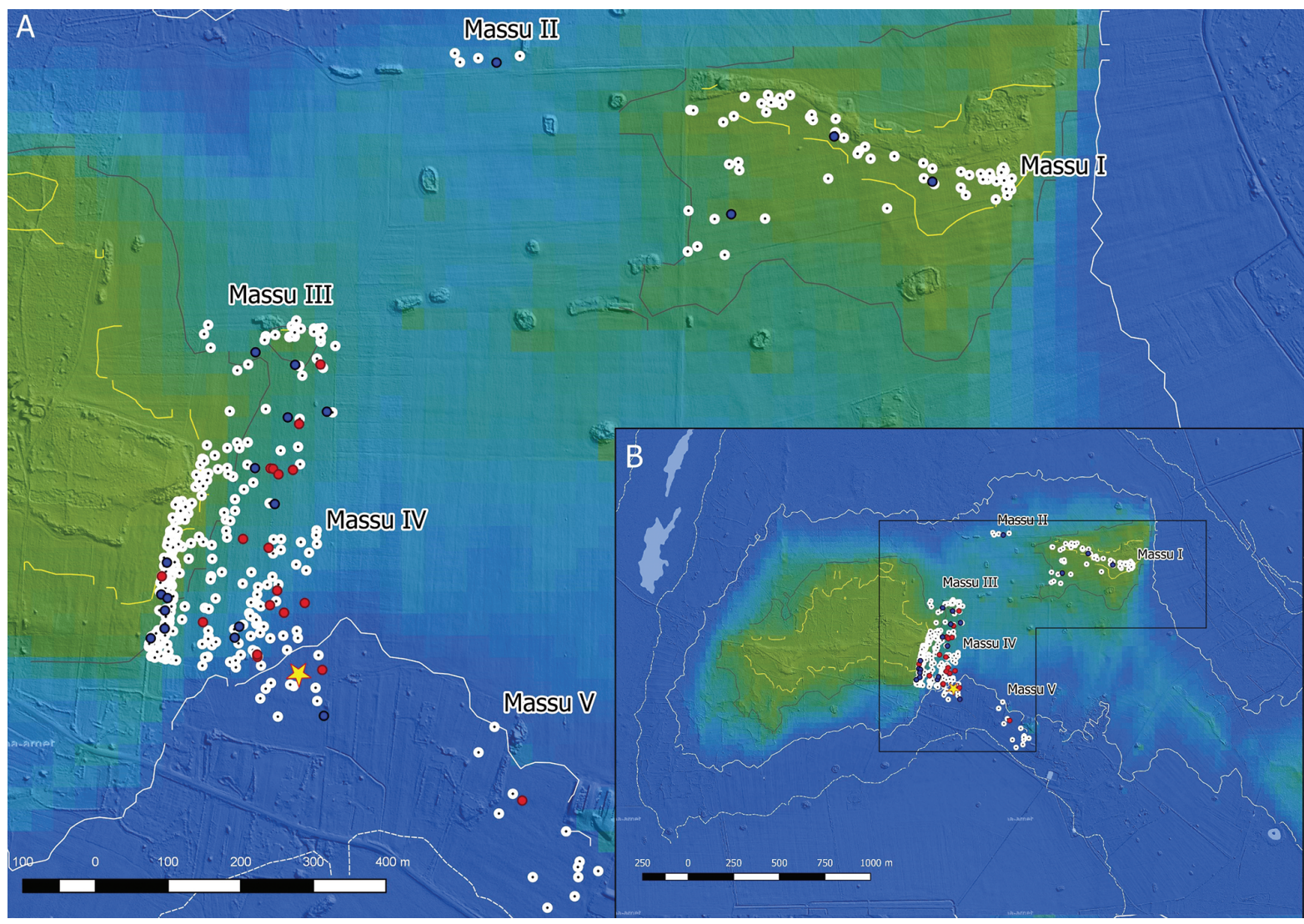

Fig. 6. The findspots of the Massu I-V sites together with paleocoastlines for 4500 cal BC (yellow), 4000 cal BC (end of the Narva stage, land denoted by green), 3000 cal BC (middle of the Comb Ware stage, white continuous line) and 2000 cal BC (final Neolithic, white dashed line) on the map of both Massu paleoislets (B) and the surroundings of the settlement sites (A). White dots: quartz, blue dots: Silurian flint, red dots: Carboniferous flint, yellow star: the rhombic bifacial arrowhead.

only a few Narva Ware sherds were previously known on the Western Estonian islands. Most of them are situated on the small Kõpu paleoisland (the highest part of the Kõpu peninsula of the present-day Hiiumaa island): Kõpu VII/VIII (Lõugas et al. 1996.205; Kriiska 1996a; 1996b; Jussila, Kriiska 2004.8), Kõpu XIII, Kõpu XVI, Kõpu X (dating to the Comb Ware stage also possible - all Jussila, Kriiska 2004) and Kõpu XIV (Rosentau et al. 2020). Of these, the Kõpu VII/VIII and Kõpu X sites have been excavated on a small scale. Pottery sherds are present among the finds gathered during the excavation of the late Narva stage Kõpu I site in a modest quantity (about 500 pottery sherds from more than 20 vessels). Lithic finds are about nine times more numerous, including a number of grinding stone fragments but only one wood chopping tool (Lõugas et al. 1996.204-206). The younger radiocarbon datings of the Pre-Pottery Võhma I settlement site on the Saaremaa island (Kriiska 2003.21) do not rule out dating to the Narva stage. Very few pottery sherds have been recovered from the Narva stage layer of the Ruhnu II site on the Ruhnu island in the
Gulf of Riga (Kriiska 2000). The aceramic Rõuste settlement site with Narva stage TPQ (Kriiska 2001a. 8, 16; 2001b.Fig. 4; 2004.172; Jussila, Kriiska 2004. 13-15) is located near the western coast of the present-day mainland (Fig. 3), at the highest part of the same coastal paleoisland where the Comb Ware Kaseküla settlement site is situated. Presently, no aceramic sites with Comb Ware stage TPQs are known on the Western Estonian islands, but that reflects the current research situation rather than trends in Neolithic landscape use.

Low assemblage diversity in general is often associated with the (seasonal) mobility of the site (e.g., Kelly 2001; case studies: Cole 2012; Eschenbrenner et al. 2017). For instance, the presence of numerous wood-chopping tools (axes, adzes, chisels) and evidence of stone grinding or polishing could be considered as indicators of diverse activities at the site, as opposed to activities associated with resource gathering and minimal tool making (Kriiska 2002a. 46-47). However, a low number of any particular find type alone cannot be interpreted as an indica- 
tor of the mobility of the site. For instance, among the numerous and diverse finds (including a large quantity of pottery sherds) of the exceptionally wellpreserved Sārnate settlement site (Latvia) with permanent dwellings, only 15 wood chopping tools and 36 grinding or polishing stones are listed (Vankina 1970.150-151, Tab. 3).

For a community that has adopted pottery, the lack or low quantity of pottery sherds in a site assemblage could be somewhat intuitively associated with mobility, especially anticipated mobility (the amount of time members of a group expect to spend at the site, Kent 1991). However, as pottery vessels of the earliest (Narva) type were mainly used for processing aquatic food (Oras et al. 2017), treating the presence of a large number of pottery sherds as a definitive indicator of sedentism would create a research bias towards considering settlement sites where aquatic resources were exploited as more sedentary, contradicting the seasonal nature of seal hunting or spawning runs of anadromous fish. The same point could either strengthen the case for the non-permanent nature of an aceramic site located near aquatic resources (especially on islands) or a suggestion that a site was used for some other reason if multiple types of resources were available (e.g., the Narva and Comb Ware phases of Kunda Lammasmäe settlement site in the North Estonian coastal zone; Sander, Kriiska 2018). As seen above, evidence of stone grinding, wood-chopping and pottery use are all very scarce among the finds of the newly discovered sites.

Besides assemblage diversity, funerals (Kriiska 2007) and pit-houses (Khrustaleva et al. 2020 and references therein) have been interpreted as markers of sedentariness. Further insights could be gained by spatial analysis and research into site structure (Kent 1991). Currently, only one presumably seasonal settlement site has been excavated on a sufficient scale and quality in Estonia (Tallinn Vabaduse väljak, Muru et al. 2017).

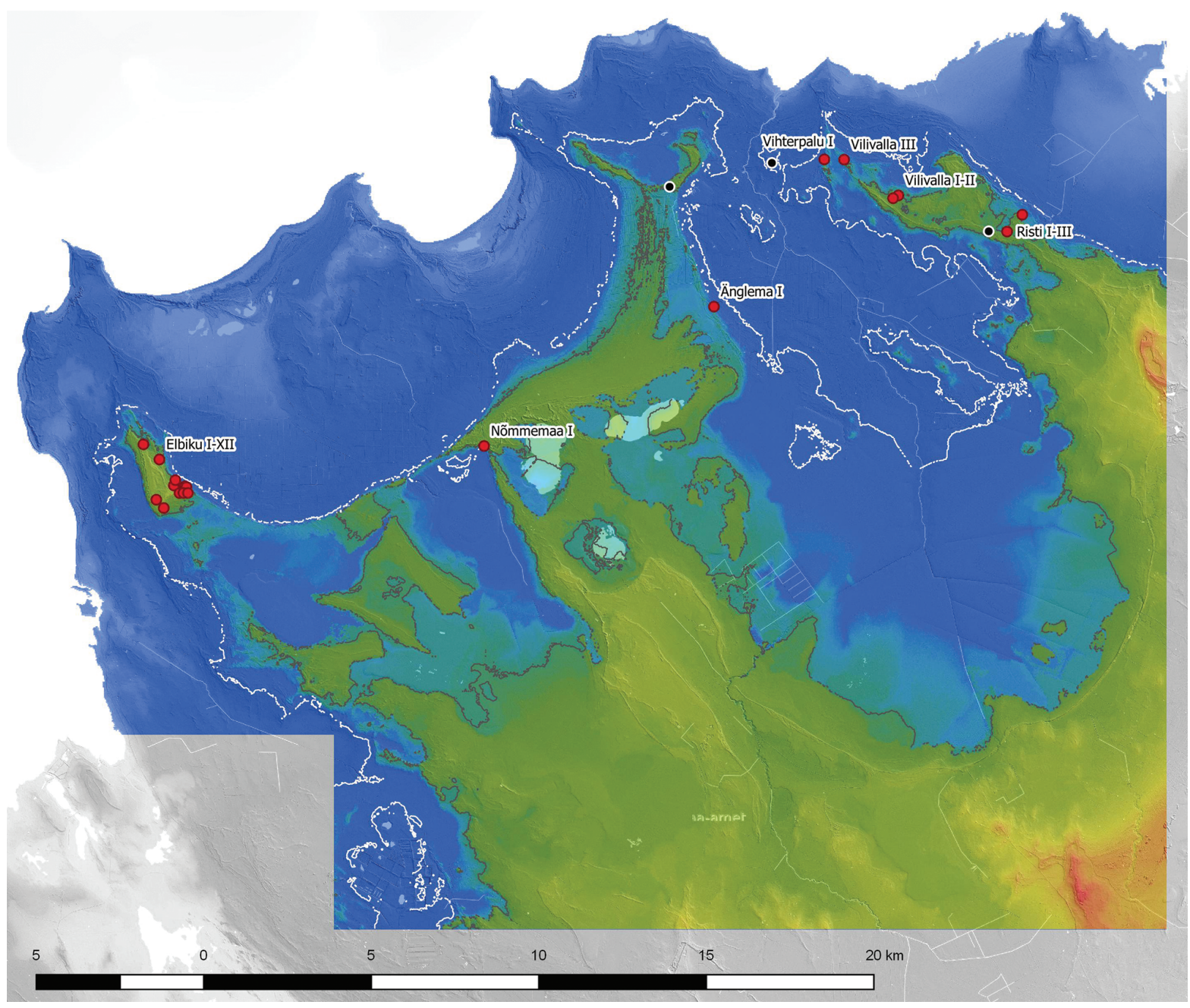

Fig. 7. Sites (red dots) and stray finds (black dots) discovered in the northern study area together with coastlines in 3500 cal BC (land denoted by green) and 2000 cal BC (white). 
Other applicable criteria for determining the site seasonality or sedentariness of mainland sites are presently lacking. Intuitively, the low faunal taxonomic diversity of zooarchaeological material recovered from a site could also be considered a marker of seasonal occupation, even if the surrounding environment supported year-round occupation. Lewis $R$. Binford (1980) formulated a forager-collector continuum of settlement systems, distinguishing between two modes of mobility, where the foragers moved their settlements to the resources (residential mobility) and collectors moved the resources to their settlements (logistical mobility). The diversity of exploited resources at a site thus supports logistical mobility and vice versa (see also Kelly 2013.77104). However, stable isotope analysis has demonstrated the prominent role of marine fish and mammals in the diet of Stone Age people buried on Saaremaa (Kõnnu, Kõljala, Naakamäe), consistent with the high share of marine mammal and fish bones in the zooarchaeological material (Tôrv 2016.165-175, 197-204; Kriiska et al. 2020.68). In other words, the diet of the buried people seems to have been in line with low taxonomic diversity of the bone material gathered from the island sites.

Methods to assess the mobility of a site based on lithic reduction strategies (e.g., Kelly 1991; Dibble et al. 2005) are not applicable for the study areas and time frame for two reasons: (1) quartz is abundantly available at least throughout coastal Estonia, and was already widely used before the LTM; (2) during the Comb Ware stage, Carboniferous flint imported over hundreds of kilometres was preferred to local Silurian flint. In addition to that, quartz was extensively used during the Comb Ware stage (apart from the early sites at least until $3700 \mathrm{cal} \mathrm{BC}$, where Carboniferous flint is overwhelmingly dominant (Kriiska et al. 2020.126)). The presence of a poorly workable but abundantly available raw material like quartz might lead to a shift towards its use instead of more efficient utilization of high quality but rarer raw materials by production of a larger number of formal tools (Manninen, Knutsson 2013). The large share of quartz among the lithic finds of the newly discovered settlement sites regardless of elevation (Tab. 1, supplement at http://dx.doi.org/10. 4312/dp.48.24) might indicate mobility for earlier Comb Ware sites.

The seasonality of the Post-LTM landscape use in Estonia has been discussed mostly in the context of the Western Estonian islands (e.g., Pre-Pottery Mesolithic Võhma I settlement site on the Saaremaa island (Kriiska 1998) and later Kõpu sites together with zooarchaeological studies (Moora, Lõugas 1995;



Fig. 8. Sites (red dots) and stray finds (black dots) discovered in the southern study area together with coastlines in 3500 cal BC (land denoted by green) and 2000 cal BC (white). 
Lõugas et al. 1996; Kriiska et al. 2017)). In general, the existence of seasonally exploited island sites with comparably low assemblage diversity on the Western Estonian islands supports the idea of the seasonality of the newly discovered mainland sites. Until the present work, no presumably seasonal Narva or Comb Ware stage mainland sites besides the Tallinn Vabaduse väljak and Kunda Lammasmägi were known, and the small number of known seasonal sites has prevented further exploration of the topic. Timo Jussila and Aivar Kriiska (2006) briefly discuss the phenomenon of 'hunting camps' but do not suggest seasonal mobility, and seasonality has been only briefly mentioned in general treatises $(\mathrm{Ja}$ anits et al. 1982.48-49, 93; Kriiska et al. 2020.6164; 112-113, but see Moora et al. 1935.52-53 discussing ethnographic parallels with the residential seasonal mobility of the indigenous Siberian peoples).

The anthropological and archaeological literature on seasonal mobility is abundant, covering most parts of the world, and much has been written about adaptations of pottery to hunter-gatherer lifestyle and mobility (e.g., Arnold 1985; Simms, Bright 1997; Gibbs 2012; Hommel 2012; Santacreu 2014; Emmitt 2017; Heitz, Stapfer 2017). Aceramic sites or sites with very few ceramic finds of people with established pottery traditions are a much less discussed phenomenon (but see Pippin 1998; Eerkens 2003; 2008; Cole 2012 about the United States Great Basin area). This owes partly to the difficulties of distinguishing the aceramic and pre-ceramic sites, and partly to the general research bias towards large sites with diverse finds (for a discussion about the American Northeast featuring climate and landscapes quite similar to the Eastern Baltics but with an adverse effect of coastline change, see Rieth 2008). From this perspective, the study areas of the current work are noteworthy for their geological properties (that make even the small 'lithic scatter' sites datable by coastal chronology), well-researched background of lithic material use and artefact typology and their size (that makes the research into aceramic modes of landscape use finally inescapable). The first two points have been discussed above. In the following passages the third point will be addressed in some detail.

While a number of settlement sites contemporary with Narva or Comb Ware stages have been interpreted as permanent in neighbouring countries (e.g., Vankina 1970; Núñez, Okkonen 2005; Berzins 2008), archaeological traces of seasonal activities are less known by far. The dwellers of the Sārnate settlement site (Latvia) have been described as an extreme case of logistical mobility during Early and Late Sārnate Ware phases (c. 4365-3780 cal BC and c. 3630-2850 cal BC, respectively, Berzins 2008 . 383). However, these logistic forays might have taken more than a day, necessitating field camps or ephemeral sites. Berzins (ibid. 391-392) discusses possible seasonal expeditions, noting that no field camp sites have been discovered so far. In Finland, Comb Ware period pit-houses are often considered a more sedentary settlement type than winter-only ones, with logistic forays similar to those postulated by Berzins (Mökkönen 2011.35-38). Small sites are known but seldom studied (but see Carpelan et al. 2008 for two examples of aceramic sites in Karelian Isthmus, Russia). The current study presents evidence not only about mostly aceramic single sites interpretable as 'field camps', but also about larger coastal areas featuring only such sites. The study areas are neighboured by three regions where more permanent settlement sites are known from the Comb Ware stage at latest: (1) the drainage basin of the Pärnu Bay south to the study areas, (2) the Northern Coastal Estonia and (3) the Western Estonia Archipelago.

Both study areas are situated north of the watershed separating the drainage basin of the Pärnu Bay from the drainage basin of the Väinameri (Fig. 1). It has been suggested (Jaanits et al. 1982.50-51; Jaanits 1992.43) that already during the Pre-Pottery Mesolithic, the drainage basin of the Gulf of Pärnu together with the area around the Lake Võrtsjärv and possibly beyond formed a social territory linked together by a communication network based on waterways. As the surveys of the inland banks of the streams flowing to the southern study area revealed very few sites and finds, we suggest that (1) the newly discovered sites were mainly accessed from the sea; (2) the rivers of the drainage basin of Väinameri did not act as a comparable communication network and 'led to nowhere' in a social or cultural geographical sense, and (3) the population of areas where more permanent settlements are known was not dense enough to necessitate colonization of the drainage basin of Väinameri. The validity of the second point depends heavily on the results of future studies of the shores of Central Estonian (paleo)lakes.

The closest known sites to the study areas interpreted as (semi)sedentary settlements in the literature are Sindi-Lodja I and II (Kriiska et al. 2002; Rosen- 
tau et al. 2011.178-179), Sindi-Lodja III (Kriiska et al. 2002; Kriiska, Lõugas 2009) and Lemmetsa I-II (Kriiska, Saluäär 2000b), situated 35-45km from the southern study area by the Audru and Pärnu rivers. The current research supports the idea of (semi)sedentary settlements by the Pärnu River and its tributaries during the Comb Ware period at latest, but possibly even during the Pre-Pottery period while the information about the Narva stage is almost totally lacking.

The Sindi-Lodja I-II Pre-Pottery Mesolithic (about 7000-6700 cal BC) sites, situated by the Pärnu River some kilometres from the paleocoastline, have been interpreted as more sedentary settlements by the thickness of cultural layer and higher find density (Kriiska, Tvauri 2002.32; Kriiska 2004.67-69; Kriiska et al. 2020.57, 62, 65) compared to the Early Mesolithic Pulli settlement site situated about 10km from the Ancylus Lake coastline by the same river (Jaanits et al. 1982.27-33; Veski et al. 2005; Kriiska, Lõugas 2009; Kriiska et al. 2020.51-54). As the relevant population sizes are not known, the validity of this suggestion is unclear. The Sindi-Lodja III site by the Pärnu River (Kriiska, Lõugas 2009; Rosentau et al. 2011.180; Kriiska et al. 2020.107) has been radiocarbon dated to the beginning of the Comb Ware stage, but pottery sherds of earlier Narva type are also present. The site features intensive cultural layers with high find densities comparable to settlement sites with dwelling remains (the Narva and Comb Ware settlement site Riigiküla I, situated by the River Narva in the North-Eastern Estonia and Jägala Jõesuu V, Khrustaleva et al. 2020 and references therein). The material found at the Lemmetsa I site by the River Audru from the later half of the Comb Ware stage is numerous and diverse, including more than $800 \mathrm{Comb}$ Ware sherds and several wood chopping tools and grinding stones gathered by fieldwalking. The find density of the nearby Lemmetsa II site is lower, but the same find types are present (Kriiska, Saluäär 2000).

Leaving apart the sites clustered near the River Narva, Northern Coastal Estonia has become the least surveyed coastal region after the present work (Fig. 1 ), with only six Comb Ware stage sites known along more than $200 \mathrm{~km}$ of northern coast, four of which have been excavated. While the Comb Ware settlements of Tallinn Vabaduse väljak and Kunda Lammasmägi clearly bear a seasonal character, the archaeological record of the settlement site of Jägala Jõesuu $V$ between them features remnants of a Comb Ware period pit-house together with numerous and diverse finds (Khrustaleva et al. 2020). Settlement patterns and pottery use along the Northern coast definitely deserve further research.

Finally, the largest paleoisland of the Western Estonian Archipelago in the central part of present-day Saaremaa (Saarse et al. 2009a; 2009b) was at least seasonally used during the Pre-Pottery Mesolithic, and most probably permanently settled during the Narva stage by the example of the Kõnnu settlement site featuring an extensive cultural layer, funerals, diverse material finds and possibly pit-houses $(\mathrm{Ja}$ anits 1979, Kriiska 1998.19; Kriiska $2001 \mathrm{~b}$ and references therein; Kriiska 2002a; Kriiska et al. 2020. 59-61).

As for utilized landscape types, the newly discovered settlement sites on the coastal islands seem to postdate the first human activity in Saaremaa and Kõpu, suggesting a dual mode of maritime activities: earlier longer sealing trips (and consequent settlement) of faraway islands, and later continuous utilization of the coastal islands, starting during the Narva stage and continuing at least until the later part of the Comb Ware stage, as attested by the Kaseküla and Massu V sites (TPQ 2600-2500 cal BC). Although the notion of mainland cape sites utilized by the Stone Age people is novel to the present work, several late Pre-Pottery Mesolithic and Narva stage sites on Saaremaa island are situated at the open coast or on small peninsulas, surrounded by the sea from three sides (Pahapilli II, Võhma VII, Võhma I).

River mouth paleolagoons have been studied in the Narva-Luga area (Rosentau et al. 2013; Kriiska et al. 2016; 2017; Ryabchuk et al. 2019) and in the Pärnu area (Veski et al. 2005; Rosentau et al. 2011; Nirgi et al. 2020). The thin barrier peninsula and islands of the Narva River mouth lagoon were used by the Stone-Age people during the Narva and Comb Ware stages (Rosentau et al. 2013.Tab. 2, Fig. 7), but no settlement sites have been discovered at the inland coast of the Narva lagoon. The Pärnu River mouth lagoon was contemporary with the Vihterpalu lagoon, having ceased to exist after the LTM and definitely before the Comb Ware, but no settlement sites are presently known from its coast.

Sites situated by the rivers or smaller streams both in the $10 \mathrm{~km}$ coastal zone and farther inland form the most numerous subgroup of Estonian Stone Age sites in the Pre-Pottery Mesolithic, Narva and Comb Ware stages (Jaanits et al. 1982, Tahvel I \& III; Sikk et al. 2020). The predominant location of the south- 
ern study area riverside sites in the coastal zone suggests that they were accessed from the sea. As the (semi)sedentary sites in the Pärnu area are all located by big rivers, it is logical to assume that the seasonal utilization of the river mouth lagoons and riversides originated from an area where the possibilities to catch anadromous fish or hunt beaver were more limited: the Western Estonian Archipelago. If that was the case, then the phenomenon of the river mouth lagoon and coastal zone riverside seasonal settlement of the Western Estonia Lowland could be explained by two factors: (1) relatively sparse population of the Pärnu area (there was no need to colonize the Western Coast beyond the drainage basin of the Gulf of Pärnu), and (2) the colonization of Saaremaa at the end of the Mesolithic, resulting in an environmentally circumscribed population interested in exploiting additional mainland resources.

Unfortunately, this suggestion is very hard to prove by archaeological material. The only lithic indicator would be artefacts made of Baltic red quartz porphyry, a raw material local to Saaremaa and Hiiumaa (and a small part of the south-western coast of the mainland (the Kaseküla site), Kriiska 2008.105). These are rare even there, amounting to only a few per cent of all lithic finds (Kriiska 2001b.Fig. 2). Furthermore, the validity of the hypothesis depends heavily on future research into Stone Age landscape use in the Northern Coastal Estonia. If the landscape use in comparable study areas in North Estonia proves similar to the areas of the current study, the Stone Age seasonal mobility of most of Estonia could be considerably higher than previously thought.

\section{Conclusion}

Most of the newly discovered sites in the study areas can be dated to the end of the Pre-Pottery Mesolithic, Narva, Comb Ware and Corded Ware stages by coastal chronology, used lithic raw materials used and artefact typology. The diversity of the material found is fairly low, as pottery sherds and wood chopping or stone grinding tools are present only on rare occasions and as single specimens. This suggests seasonal use of the sites similar to the Narva stage sites on the Western Estonian islands, especially the Kõpu paleoisland. The notion of large areas featuring only seasonal sites during the Estonian Narva and Comb Ware stages is novel to the present work.

In addition to the previously known sites on the Western Estonian islands, the utilization of capes open to the sea can be observed on the mainland (novel to the present work). Besides capes, the paleolagoons at the past river mouths feature clusters of settlement sites similar to the Narva-Luga area in North-Eastern Estonia. At latest during the Narva stage, small coastal islands located up to $15 \mathrm{~km}$ from the coast became extensively used. While the earlier utilization of the $10 \mathrm{~km}$ coastal zone riversides is probable, the majority of the newly discovered riverside sites feature Carboniferous flint with very few blades, making it possible to date them to the Comb Ware stages even in the absence of pottery finds. The finds from banks of the tributaries of the River Kasari further away from the coast are very rare, suggesting that the coastal zone sites were accessed from the sea. This is radically different from the neighbouring drainage basin of the Pärnu Bay, where the Rivers Pärnu and Navesti formed a part of a communication network leading to the Lake Võrtsjärv region, featuring a large number of Stone Age settlement sites. This finding is in line with the very low number of known sites in Central Estonia north to the Lake Võrtsjärv region. As the River Kasari and its tributaries might have 'led to nowhere' in the social or cultural geographic senses.

The findings of the present work suggest the persistence of established landscape use patterns and the additive nature of spatial extension of subsistence strategies. This can be divided into three phases:

- at least seasonal utilization of Saaremaa and Kõpu already during the Pre-Pottery Mesolithic, concurrent with the mainland coastal sites of the study areas situated at capes or river mouths;

- the utilization of the coastal islands, probably starting during the Narva stage;

- the utilization of the mainland streams in the $10 \mathrm{~km}$ coastal zone during the Comb Ware stage.

The utilization of capes and coastal islands started earliest and continued during the Comb Ware stages, as attested by the newly discovered Vihterpalu I (TPQ 3300 cal BC), the previously known Kaseküla and newly discovered Massu V sites (TPQ 2600$2500 \mathrm{cal} \mathrm{BC}$ ), while the overwhelming majority of the sites by the rivers and brooks of the southern study area probably originate from the Comb Ware stage. This additive model of spatial expansion of human activities is novel to the present work.

The study areas are neighboured by regions where settlement sites with intensive cultural layers, larger find diversities, funerals or remains of pit-houses can be dated at latest to the Narva (Saaremaa island) 
or the Comb Ware stages (the drainage basin of the Pärnu Gulf and Northern Coastal Estonia). One possibility to explain the findings of the present work is the hypothesis that the seasonal human activity originated from the Western Estonian Archipelago with an environmentally circumscribed population interested in exploiting additional mainland resources. The validity of this suggestion depends heavily on future studies of the landscape use of Northern Coastal Estonia: if study areas of similar size along the northern coast exhibit patterns similar to the study areas of the present work, then the seasonal mobility of most of Estonia rather than some particular region should be considered higher than previously thought.

\section{ACKNOWLEDGEMENTS}

This work was supported by the Estonian Research Council research project PRG243, the base financed project PHVAJ20919 of the Institute of History and Archaeology of the University of Tartu and Arheograator Ltd. The work is based on datasets: Estonian Land Board 2021. Digital Terrain Model. Estonian maps and topographic data, and Estonian Land Board 2017. Digital Soil Map. The work uses computer programmes: CloudCompare 2.10.2 Zephyrus. 2020. www.cloudcompare.org, and Quantum GIS 3.0.3 Girona. 2018. www.qgis.org. The authors are grateful to all participants of the fieldwork and to $\mathrm{Ms}$. Ly Kriiska for supporting the expeditions. Our special thanks belong to the reviewers of the paper.

\section{$\therefore$}

\section{References}

Arnold D. E. 1985. Ceramic theory and cultural process. Cambridge University Press. London.

Bērzin̄š, V. 2008. Sārnate: living by a coastal lake during the East Baltic Neolithic. Unpublished PhD thesis. Faculty of Humanities. University of Oulu. http://jultika.oulu.fi/files/isbn9789514289415.pdf

Binford L. R. 1980. Willow Smoke and Dogs' Tails: Hunter-Gatherer Settlement Systems and Archaeological Site Formation. American Antiquity 45(1): 4-20. https://doi.org/10.2307/279653

Carpelan C., Uino P., and Gerasimov D. 2008. Archaeology in the former municipality of Johannes. In M. Lavento, K. Nordqvist (eds.), Karelian Isthmus: Stone Age Studies in 1998-2003. Iskos 16. The Finnish Antiquarian Society. Helsinki: 185-211.

Cole C. R. 2012. Prehistoric Archaeology and the Fremont Frontier at North Meadow Valley Wash, Eastern Nevada. Unpublished PhD Thesis. University of California. Davis. https://www.proquest.com/docview/1027415 395 ? pq-origsite $=$ gscholar\&fromopenview $=$ true

Dibble H. L., Schurmans U., Iovita R. P., and McLaughlin M. V. 2005. The Measurement and Interpretation of Cortex in Lithic Assemblages. American Antiquity 70(3): 545-560. https://doi.org/10.2307/40035313

Eerkens J. W. 2003. Residential Mobility and Pottery Use in the Western Great Basin. Current Anthropology 44(5): 728-738. DOI:10.1086/379262
2008. Nomadic Potters. Relationships between ceramic technologies and mobility strategies. In H. Barnard, W. Wendrich (eds.), The Archaeology of Mobility: Old World and New World Nomadism. Cotsen Institute of Archaeology. Los Angeles: 307-326.

Emmitt J. J. 2017. The Neolithic Pottery of Egypt: Investigating settlement pattern in middle Holocene northeast Africa with ceramics. Unpublished PhD thesis. The University of Auckland. Auckland.

https://doi.org/10.13140/RG.2.2.12527.33445

Eschenbrenner J. H., Edwards A. R., Hall-Holton J., Jaege E., Johnson R., and Walton C. 2017. The Archaeology of High Prairie, Idaho. Idaho Archaeologist 40(1): 21-66.

Gibbs K. 2012. Not meant to last: mobility and disposable pottery. Documenta Praehistorica 39: 83-93.

https://doi.org/10.4312/dp.39.6

Grudzinska I., Saarse L., Vassiljev J., and Heinsalu A. 2013. Mid- and late-Holocene shoreline changes along the southern coast of the Gulf of Finland. Bulletin of the Geological Society of Finland 85(1): 19-34.

https://doi.org/10.17741/bgsf/85.1.002

Hang T., Veski S., Vassiljev J., Poska A., Kriiska A., and Heinsalu A. 2020. A new formal subdivision of the Holocene Series/Epoch in Estonia. Estonian Journal of Earth Sciences 69: 269-280.

https://doi.org/10.3176/earth.2020.15 
Heitz C., Stapfer R. 2017. Mobility and pottery production. Archaeological \& anthropological perspectives. Sidestone Press. Leiden.

Hommel P. N. 2012. The Emergence of Ceramics among Hunter-gatherers in Northern Eurasia: The Neolithic Ceramics of the Upper Vitim Basin, Northern Transbaikal, Siberia. Unpublished PhD thesis. Faculty of Arts and $\mathrm{Hu}$ manities. University of Sheffield. Sheffield. https:/etheses. whiterose.ac.uk/24574/1/Thesis\%E2\%80\%94Hommel.pdf

Yanits L. Yu. 1959. Poseleniya epokhi neolita i rannego metalla v priust'ye r. Emayygi (Estonskaya SSR). Akademiya Nauk Estonskoi SSR. Tallinn. (in Russian)

Jaanits L. 1979. Die neolithische Siedlung Kõnnu auf der Insel Saaremaa. Eesti NSV Teaduste Akadeemia Toimetised. Ühiskonnateadused 4(4): 363-367.

1992. Põllumajanduse eelduste kujunemine. In J. Kahk, E. Tarvel (eds.), Eesti talurahva ajalugu 1. Olion. Tallinn: $42-56$.

Jaanits L., Laul S., Lõugas V., and Tõnisson E. 1982. Eesti esiajalugu. Eesti Raamat. Tallinn.

Jaanits K., Ilomets M. 1988. Umbusi mesoliitilise asula vanusest ja kohast Eesti keskmise kiviaja kronoloogias. In A.-M. Rõuk, J. Selirand (eds.), Loodusteaduslikke meetodeid Eesti arheoloogias. Academy of Sciences of the Estonian SSR. Tallinn: 54-64.

Jussila T., Kriiska A. 2004. Shore displacement chronology of the Estonian Stone Age. Estonian Journal of Archaeology 8(1): 3-32.

2006. Pyyntikultuurin asuinpaikkojen rantasidonnaisuus. Uusia näkökulmia Suomen ja Viron kivi- ja varhaismetallikautisten asuinpaikkojen sijoittumiseen. In P. Pesonen, T. Mökkönen (eds.), Arkeologia ja kulttuuri. Uutta kivikauden tutkimuksessa, Arkeologipäivät 2005. Suomen arkeologinen seura. Hamina: 36-49.

Kelly R. 2001. Prehistory of the Carson Desert and Stillwater Mountains: Environment, Mobility, and Subsistence in a Great Basin Wetland. University of Utah Press. Salt Lake City.

2013. The lifeways of hunter-gatherers. The foraging spectrum. $2^{\text {nd }}$ ed. Cambridge University Press. New York.

Kent 1991 . The relationship between mobility strategies and site structure. In E. N. Kroll, T. D. Price (eds.), The interpretation of archaeological spatial patterning. Springer. New York.
Khrustaleva I., Roog R., Kholkina M., and Kriiska A. 2020. Hunter-gatherer pit-houses in Stone Age Estonia. Archaeological and Anthropological Sciences 12(2): UNSP 56. https://doi.org/10.1007/s12520-020-01018-0

Kriiska A. 1996a. Archaeological studies on the Kõpu Peninsula. Proceedings of the Estonian Academy of Sciences. Humanities and Social Sciences 4: 398-409.

1996b. Viron rannikkoalueen asutus ja pyyntikulttuurin erikoistuminen kivikaudella. Muinastutkija 4: 1-6.

1997. Kroodi ja Vihasoo III asula Eesti varaneoliitiliste kultuurirühmade kontekstis. Estonian Journal of $A r$ chaeology 1: 7-25.

1998. Mesoliitilised asustusjäljed Loode-Saaremaal. Ajalooline Ajakiri. The Estonian Historical Journal 100 (1): 13-22.

2001a. Lääne-Eesti mandriosa kiviaja äärejooni. Läänemaa muuseumi toimetised $V:$ 7-40.

2001b. Stone Age settlement and economic processes in the Estonian coastal area and islands. Unpublished PhD thesis. Faculty of Arts. University of Helsinki. Helsinki.

2002a. Lääne-Eesti saarte asustamine ja püsielanikkonna kujunemine. In V. Lang (ed.), Keskus - tagamaa ääreala. Uurimusi asustushierarhia ja võimukeskuste kujunemisest Eestis. Centre - Hinterland - Margin. Studies in the Formation of Settlement Hierarchy and Power Centres in Estonia. University of Tallinn and University of Tartu. Tallinn, Tartu.

2002b. Maa ja mere piiril. Inimasustuse algus Paikuse piirkonnas. Kahe jõe vahel. Meie elu läbi aegade 1: 5-12.

2003. Colonisation of the west Estonian archipelago. In H. Kindgren, K. Knutsson, L. Larsson, and D. Leoffler (eds.), Mesolithic on the Move: Papers Presented at the Sixth International Conference on the Mesolithic in Europe. Oxbow Books. Oxford: 20-28.

2004. Aegade alguses: 15 kirjutist kaugemast minevikust. A. Kriiska. Tallinn.

2007. Saaremaa kiviaeg. In K. Jänes-Kapp, E. Randma, and M. Soosaar (eds.), Saaremaa. Ajalugu, majandus, kultuur. Koolibri. Tallinn: 9-36.

2008. Primorskaya adaptatsiya i zaseleniye Zapadno-Estonskikh ostrovov Baltiyskogo morya v kamennom veke. In G. A. Khlopachev (ed.), Problemy biologicheskoy $i$ kul'turnoy adaptatsii chelovecheskikh populyatsiy. Nauka. Sankt-Peterburg: 98-118. (in Russian) 
2015. Foreign Materials and Artefacts in the $4^{\text {th }}$ and $3^{\text {rd }}$ Millennia BCE Estonian Comb Ware Complex. In P. Espak, M. Läänemets, and V. Sazonov (eds.), When Gods Spoke. Researches and Reflections on Religious Phenomena and Artefacts. Studia in honorem Tarmo Kulmar. Tartu University Press. Tartu: 107-124.

Kriiska A., Gerasimov D. V., Nordqvist K., Lisitsyn S. N., Sandel S., and Kholkina M. A. 2016. Stone Age research in Narva-Luga Klint Bay area (2005-2014). New sites, new methods. Iskos 21. The Finnish Antiquarian Society. Helsinki: 101-115.

Kriiska A., Johanson K., Saluäär U., and Lõugas, L. 2003. The results of research of Estonian Stone Age in 2002. Archeological fieldwork in Estonia 2002: 30-43.

Kriiska A., Khrustaleva I. 2020. Inside the Dwelling: Clay Figurines of the Jägala Jõesuu V Stone Age Settlement Site (Estonia). Baltic Journal of Art History 20: 11-57. https://doi.org/10.12697/BJAH.2020.20.01

Kriiska A., Lang V., Mäesalu A., Tvauri A., and Valk H. 2020. Eesti ajalugu I. Eesti esiaeg. Tartu Ülikooli Ajalooja Arheoloogia Instituut. Tartu.

Kriiska A., Lõugas L. 2005. Formation of Ruhnu Island and its early settlement history. In Talvi T. (ed.), Nature of Ruhnu Island. Lääne-Eesti Saarestiku Biosfääri Kaitseala. Viidumäe: 123-152.

2009. Stone Age settlement sites on an environmentally sensitive coastal area along the lower reaches of the River Pärnu (southwestern Estonia), as indicators of changing settlement patterns, technologies and economies. In S. McCartan, R. Schulting, C. Warren, and P. Woodman (eds.), Mesolithic Horizons. Papers Presented at the Seventh International Conference on the Mesolithic in Europe, Belfast 2005, I. Oxbow Books. Oxford: $167-175$.

Kriiska A., Lõugas L., and Saluäär U. 1998. Archaeological excavations of the Stone Age settlement site and ruin of the stone cist grave of the Early Metal Age in Kaseküla. Archeological fieldwork in Estonia 1997: 30-43.

Kriiska A., Mandel M. 1996. Aruanne arheoloogilisest inspektsioonist Läänemaale 25.-26.04 ja 4.-5.09. 1996. Report archived at National Heritage Board. Tallinn.

Kriiska A., Oras E., Lõugas L., Meadows J., Lucquin A., and Craig 0. E. 2017. Late mesolithic Narva stage in Estonia: pottery, settlement types and chronology. Estonian Journal of Archaeology 21(1): 52-86.

https://doi.org/10.3176/arch.2017.1.03
Kriiska A., Rappu M., Tasuja K., Plado J., and Šafranovski J. 2009. Archaeological research in Jägala. Archaeological Fieldwork in Estonia 2008: 36-52.

Kriiska A., Saluäär U. 2000a. Archaeological fieldwork on the island Ruhnu. Archeological fieldwork in Estonia 1999: 18-43.

2000b. Lemmetsa ja Malda neoliitilised asulakohad Audru jõe alamjooksul. In A. Vunk (ed.), Pärnumaa ajalugu 3. Pärnu Maavalitsus. Pärnu: 8-38.

Kriiska A., Saluäär U., Lõugas L., Johanson K., and Hanni H. 2002. Archaeological excavations in Sindi-Lodja. Archaeological fieldwork in Estonia 2001: 27-40.

Kriiska A., Sikk K. 2014. Archaeological test excavations at the Mesolithic and Iron Age settlement site Jägala-Joa IV. Archeological fieldwork in Estonia 2013: 45-54.

Kriiska A., Tvauri A. 2002. Eesti muinasaeg. Avita. Tallinn.

Laid E. 1931. Kodumaa asustus muinasajal. Eesti kirjandus 7: 353-367.

Laneman M. 2012. Stone-cist grave at Kaseküla, western Estonia, in the light of AMS dates of the human bones. Estonian Journal of Archaeology 16(2): 91-117. https://doi.org/10.3176/arch.2012.2.01

Lang V. 2007. Baltimaade pronksi- ja rauaaeg. Tartu Ülikooli Kirjastus. Tartu.

Lõugas L., Kriiska A., and Moora H. 1996. Coastal Adaptation and Marine Exploitation of the Island Hiiumaa, Estonia, During the Stone Age with Special Emphasis on the Kõpu I Site. In A.-M. Robertsson, A. Åkerlund, and S. Hicks (eds.), Landscapes and life: studies in honour of Urve Miller. PACT Belgium. Rixensart: 197-211.

Mandel M. 1975. Ausgrabungen der Steingräber von Kaseküla. Eesti NSV Teaduste Akadeemia Toimetised. Ühiskonnateadused 1: 74-76.

1991. Lihula 1987. a. arheoloogiliste kaevamiste aruanne. Report archived at National Heritage Board, Tallinn, Estonia.

Manninen M. A., Knutsson K. 2013. Lithic raw material diversification as an adaptive strategy - Technology, mobility, and site structure in Late Mesolithic northernmost Europe. Journal of Anthropological Archaeology 33: 8498. https://doi.org/10.1016/j.jaa.2013.12.001

Moora H., Laid E., Mägiste J., and Kruus H. 1935. Eesti ajalugu I. Esiajalugu ja muistne vabadusvõitlus. Eesti Kirjanduse Selts. Tartu. 
Moora H., Lõugas L. 1995. Natural conditions at the time of primary habitation of the Hiiumaa Island. Proceedings of the Estonian Academy of Sciences. Humanities and Social Sciences 44(4): 472-481.

Muru M., Rosentau A., Kriiska A., + 7 authors, and Kihno K. 2017. Sea level changes and Neolithic hunter-fishergatherers in the centre of Tallinn, southern coast of the Gulf of Finland, Baltic Sea. The Holocene 27(7): 917-928. https://doi.org/10.1177/0959683616678462

Muru M., Rosentau A., Preusser F., + 5 authors, and Kriiska A. 2018. Reconstructing Holocene shore displacement and Stone Age palaeogeography from a foredune sequence on Ruhnu Island, Gulf of Riga, Baltic Sea. Geomorphology 303: 434-445.

https://doi.org/10.1016/j.geomorph.2017.12.016.

Mökkönen T. 2011. Studies on Stone Age Housepits in Fennoscandia (4000-2000 cal BC): Changes in ground plan, site location and degree of sedentism. Unpublished PhD thesis. Faculty of Arts. University of Helsinki. Helsinki. https://helda.helsinki.fi/handle/10138/26492

Nirgi T., Rosentau A., Habicht H.-L., + 9 authors, and Tõnisson H. 2020. Holocene relative shore-level changes and Stone Age palaeogeography of the Pärnu Bay area, eastern Baltic Sea. The Holocene 30(1): 37-52. https://doi.org/10.1177/0959683619865603

Núñez M., Okkonen, J. 2005. Humanizing of north Ostrobotnian landscapes during the $4^{\text {th }}$ and $3^{\text {rd }}$ millennia. Journal of Nordic Archaeological Science 15: 25-38.

Oras E., Lucquin A., Lõugas L., Tõrv M., Kriiska A., and Craig 0. E. 2017. The adoption of pottery by north-east European hunter-gatherers: Evidence from lipid residue analysis. Journal of Archaeological Science 78: 112-119. https://doi.org/10.1016/j.jas.2016.11.010

Orru M. 2020. Estonian Peat Database. turba.geoloogia.info

Pippin L. C. 1998. Hunter-gatherer adaptations and environmental change in the southern great basin: the evidence from Pahute and Rainier Mesas. Technical Report no. 92. Quaternary Sciences Center. Desert Research Institute. University and Community College System of Nevada. Reno.

Rieth C. B. (ed.) 2008. Current approaches to the analysis and interpretation of small lithic sites in the northeast. New York State Education Department. Albany.

Rosentau A., Muru M., Kriiska A., + 10 authors, and Letyka N. 2013. Stone Age settlement and Holocene shore displacement in the Narva-Luga Klint Bay area, eastern Gulf of Finland. Boreas 42(4): 912-931.

https://doi.org/10.1111/bor.12004.

Rosentau A., Nirgi T., Muru M., + 6 authors, and Kriiska A. 2020. Holocene relative shore level changes and Stone Age hunter-gatherers in Hiiumaa Island, eastern Baltic Sea. Boreas 49(4): 799-812.

https://doi.org/10.1111/bor.12452

Rosentau A., Veski S., Kriiska A., + 5 authors, and 0ja T. 2011. Palaeogeographic model for the SW Estonian coastal zone of the Baltic Sea. In J. Harff, S. Björck, and P. Hoth (eds.), The Baltic Sea Basin. Springer. Berlin: 165188.

Ryabchuk D. V., Sergeev A. Y., Gerasimov D. V., + 6 authors, and Terekhov A. V. 2019. New data on the postglacial development of Narva-Luga Klint Bay (Eastern Gulf of Finland): results of geoarchaeological research. Journal of Coastal Conservation 23: 727-746.

https://doi.org/10.1007/s11852-018-0670-5

Saarse L., Vassiljev J., and Miidel A. 2003. Simulation of the Baltic Sea shorelines in Estonia and neighbouring areas. Journal of Coastal Research 19(2): 261-268.

Saarse L., Vassiljev J., Miidel A., and Niinemets E. 2006. Holocene buried organic sediments in Estonia. Proceedings of the Estonian Academy of Sciences. Geology 55(4): 296-320.

Saarse L., Vassiljev J., and Rosentau A. 2009a. Ancylus Lake and Litorina Sea transition on the Island of Saaremaa, Estonia: a pilot study. Baltica 22(1): 51-62.

2009b. Litorina Sea shore displacement on the Island of Saaremaa, Estonia. Polish Geological Institute Special Papers 25: 59-66.

Sander K., Kriiska A. 2018. New archaeological data and paleolandscape reconstructions of the basin of an Early and Middle Holocene lake near Kunda, North-Eastern Estonia. Fennoscandia Archaeologica XXXV: 65-85.

Santacreu D. A. 2014. Materiality, Techniques and Society in Pottery Production. The Technological Study of Archaeological Ceramics through Paste Analysis. De Gruyter Open. Warsaw.

Sikk K., Kriiska A., Johanson K., Sander K., and Vindi A. 2020. Environment and settlement location choice in Stone Age Estonia. Estonian Journal of Archaeology 24 (2): 89-140. https://doi.org/10.3176/arch.2020.2.01

Simms S. R., Bright J. R. 1997. Plain-ware ceramics and residential mobility: a case study from the great basin. Journal of Archaeological Science 24: 779-792. 
Tšugai A., Plado J., Jõeleht A., + 4 authors, and Rosentau A. 2014. Ground-penetrating radar and geological study of the Kudruküla stone age archaeological site, Northeast Estonia. Archaeological Prospection 21(3): 225-234. https://doi.org/10.1002/arp.1484

Tvauri A., Johanson K. 2006. Archaeological Research on Kavastu Mesolithic and Early Modern Settlement Site in 2005. Archeological fieldwork in Estonia 2002: 41-46.

Tõnisson E. 2008. Eesti muinaslinnad. Prehistoric strongholds of Estonia. Muinasaja teadus 20. Tartu Ülikool. Tallinna Ülikooli ajaloo instituut.Tartu, Tallinn.

Tõrv M. 2016. Persistent practices. A multi-disciplinary study of hunter-gatherer mortuary remains from $c$.
6500-2600 cal BC, Estonia. PhD thesis. Institute of History and Archaeology, Faculty of Arts and Humanities, University of Tartu, Estonia Dissertationes Archaeologiae Universitatis Tartuensis 5. University of Tartu Press. https://dspace.ut.ee/bitstream/handle/10062/51352/tor v_mari.pdf?sequence $=1$ \&isAllowed $=\mathrm{y}$

Vankina L. V. 1970. Torfyanikovaya stoyanka Sarnate. Zinatne. Riga. (in Russian)

Veski S., Heinsalu A., Klassen V., Kriiska A., Lõugas L., Poska A., and Saluäär U. 2005. Early Holocene coastal settlements and palaeoenvironment on the shore of the Baltic Sea at Parnu, southwestern Estonia. Quaternary International 130: 75-85.

https://doi.org/10.1016/j.quaint.2004.04.033 